\title{
The using of readutainment as e-learning to improve students' reading comprehension skill
}

\author{
Nina Dwiastuty*, Susilawati, and Muhammad Sulhan \\ The University of Indraprasta PGRI, Jakarta, Indonesia
}

\begin{abstract}
Technology grows and has changed life styles in many aspects. It offers simplicity and practicality to human to switch the life easier from traditional to modern creativity. In the education context, the use of elearning as a product of technology in the language learning is inevitable and has made language teachers find new teaching strategies. This action research aims to prove whether the innovation of Readutainment application as e-learning enables students to improve their reading comprehension skill. This application usage is to facilitate students to comprehend. English texts. The research object were private vocational students of grade XI taken from 6 of 12 vocational schools in the districts of Singaparna and Leuwisari, West Java. It uses a purposive random sampling by considering that all students are homogeneous in their cognitive levels. The method of this research is qualitative action based on students' studying in the cloud classrooms in two cycle designs. The result shows that the use of Readutainment can improve students' ability to comprehend English texts. It is proven that after being treated by using the Readutainment in two cycles, the average score increases from 68 to 70 in the first cycle and 75 in the second cycle.
\end{abstract}

\section{Introduction}

The concept of teaching and learning has been, these days, switching from conventional to more creative one as the impact of the fast growing of information technology. The conventional way of teaching is, in one hand, still mostly applied in which the activity of teaching and learning occur face-to-face in the classrooms. The more creative way of teaching in this modern-gadget era, on the other hand, requires educators to have no choice but consequently apply it anyway. The process of teaching and learning can be done through e-learning in the cyberspace as a new concept. In short, the teaching and learning process does not mainly depend on space and time due to the presence of internet that has been widely used in the form of e-learning.

The use of e-learning in education becomes very possible to be implemented in line with the fact that most people connect with internet for many purposes. Survey on internet usage done by the Indonesia Internet Service Provider Association or Asosiasi Penyelenggara Jasa Internet Indonesia found that in 2016, internet users reached up to 132 million people. How people access internets vary in some ways as such that 2 million of them or 50.7 percent access internet via smartphones and computers, 63.1 million people or 47.6 percent access internet via smartphones, and 2.2 million people or 1.7 percent access internet only via computers. (Kompas.com, Oct. 24, 2016). This indicates that teachers and students very possibly furnish themselves with smartphones which are not only used for communication but for accessing internet as well. Therefore, teacherstudent interaction can be built via e-learning in the process of teaching and learning at anytime and anywhere.

E-learning is worth implementing as an alternative in which teachers, for example, have another way of delivering their teaching materials to students outside the classrooms (Mohammadi et al., 2011:464-468). Though lesson plans have been previously prepared, teachers might often face problems of time arrangement to discuss all teaching material as planned in one meeting in the classrooms. It was due to two different factors; practical factor and professional factors. The practical factor refers to the large number of students in class, class size, time allotment, lack of appropriate resources to support the implementation of the approach. While, professional factors may cover the teacher preparations, mastery of the discussed topics, and teaching-learning strategies (Marcellino, 2008). Hence, students have insufficient of time to deliver questions for unclear matters and teachers may not satisfy their explanation to the students due to the limited time. Another problem emerges in such a way that teachers lost opportunity to fully concentrate in the teaching activities. Teaching in a crowded classroom can cause failure to attract students' attention and involvement as some students may make noises and not focus in the learning process.

In the Indonesian context, e-learning has been arising as research subject and continuously developed in the teaching and learning practices. It was previously hard to find references and research findings on the concept of

\footnotetext{
* Corresponding author: ninadwiastuty@yahoo.com
} 
learning in the virtual classrooms by using e-learning in Indonesia. Rather, most educators discussed mostly about how to teach and learn effectively in the real classrooms (Damayanti et. al., 2007). However, the rapid changing in the Information and Communication Technology (ICT) has encouraged teachers and lecturers to do research on the effectiveness of using e-learning in their related knowledge background. In short, the stakeholders in the education have realized that the teaching and learning do not, anymore, depend on face-to-face meeting in the real classrooms.

At least, two examples of research might represent to prove that e-learning affects significantly in the teaching and learning of certain subjects. First, Daud and Rahmadana (2015) conducted a research and development (R \& D) to develop an educational product; that is, Biology Instructional Media Based E-learning for Excretion System Concepts at Class XI IPA3 SMAN 4 Makassar and to validate its usage. They implemented a software called Joomla and Wondershare Quiz Creator (WQR) for the evaluation tool. They applied 5 steps in this R \& D; (1) Conducting first study, (2) Designing the product, (3) Developing the first product, (4) Trials and revision of the first product, and (5) Trials and revision of final product. The result shows that the biology instructional media based e-learning by using Joomla and WQC is considered valid, practical, and effective.

Another research done by Suharyanto and Mailangkay (2016) conclude that e-learning contributes a positive and significant impact on the quality of learning. The influence is strong confirming that the more intensive elearning is used, the quality of learning will be increasing. These conclusions derive from their investigation and analysis of other researchers' findings on the using of elearning in some educational institutions The data were taken from 5 (five) researchers; (1) Edy conducted a study in 2011 in Central Java, (2) Budi conducted a study in 2012 in the Directorate of Diploma Program of the Institute of Agriculture Bogor, (3) Agustina conducted a study in 2013 in the University of Bina Darma, (4) Tiara conducted a study in 2015 in SMA Negeri 4, Jember-East Java, and (5) Harahap conducted a study in 2015 in the Faculty of Economy in UMSU. It can be said that this is an indirect research as all data were taken from the researchers' findings.

Being inspired by the above previous studies, the researchers offer a product of e-learning called Readutainment application to be implemented in this current research. It is true that the application is not really new in the e-learning innovation product especially in language learning. In fact, the similar products can be easily found in the internet these days. However, the researchers have made some modification from the existing application to comply with Indonesian higher school students' levels of thinking.

The name Readutainment deals with entertaining reading activities while its users may also sharpen and enrich the other features of language such as vocabulary, part of speech, etc. Exercises and discussion which come after the texts may foster students to reach understanding. In short, it is expected that this application enables students to improve their EFL reading skill achievement.
The research question would be, then, stated as: Can the use of Readutainment as e-learning improve students' reading comprehension skill?

The researchers focus on the students' reading skill improvement because it is considered difficult to the Indonesian EFL students. In most cases, EFL students do not have good English reading habit although they have formally learned English from elementary school (Iftanti, 2012). They are lack of reading strategy consequently and even fail to get the message of the English texts due to insufficient or limited vocabularies. It is perhaps because English teachers fail to guide students to have higher levels of thinking in the reading classrooms. Instead, the teaching or reading comprehension occur in the lower levels of cognition (Sulhan, 2015). This may lead to the failure on students' effort to catch the writer's message in the English reading texts.

As a matter of fact, reading is the construction of meaning from a printed or written message and material (Richards, 1998:12; Fox, 2015:12) and the meaning itself is always contextual, generated from the interaction between long-term memory traces and the momentary context existing in working memory (Kintsch and Mangalath, 2011). Moreover, the nature of reading arises in its multiple forms and purposes (Blachowi and Donna, 2008:13). It implies that written texts consist of words, phrases, clauses, and sentences to build meaning as the authors' idea to be delivered to the readers. In order to reach comprehension, the readers will automatically connect the information from the written message with the previous knowledge. However, the process of connecting the readers and their experience depends on the sociocultural context which mediates students' experiences, just as students' experiences influence the context (https://www.rand.orgcontentdamrandpubsmono graph rep ortsMR1465MR1465.ch2.pdf).

If the text message is successfully caught through appropriate strategies, reading may empower, bewitch, enrich the experience because it appears to be superficially and parasitically, waving, tool making gathering, face and gender recognition and any others, whereby a flood of visual data-shapes, units, patterns, orientation, sequencing- is assessed at a glance (Fischer, 2003:7).

The flowchart below simply figures out the framework proposed in this research to show how e-learning as a creative teaching and learning model (a product of technology) in in the form of Readutainment application is expected to improve students' reading comprehension skill.

\section{Research Method}

The sample of this current classroom action research were totally 180 students in Singaparna and Leuwisari, West Java which were randomly taken from 6 (six) private vocational schools in these districts. It means that 30 (thirty) students involved as the representative participants of each school. The researchers used the Edmodo network as the artificial platform to accommodate students in the virtual classrooms in the 
cloud. There were 6 virtual classrooms established and all students were hoped to actively engage in the teaching and learning of reading comprehension by using Readutainment application through this network into cycles of teaching as the design of action research. The researchers shared the teaching materials which have been set in the application and let students access it at any convenient time and anywhere.

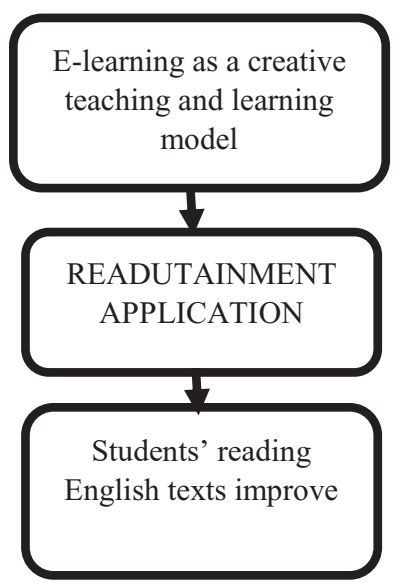

Fig 1. Flowchart of framework of thinking

The said application contains reading comprehension texts complete with exercises and discussion, quizzes and assignments. It provides mini dictionaries or glossaries of word classes following the texts. When students click VERB, for example, all verbs in the text highlight automatically showing its particular green color background and the Indonesian translations can be found beside it. The students may move to click the other word classes and the same results emerge spontaneously. In addition, the comprehension strategy offered in the Readutainment application is expected to strengthen the students' previous reading capability. The improvement scores can be measured as they were assigned to submit their works after completing all multiple choice exercises. Importantly, the cycle of teaching would have been stopped until the scores were averagely increasing.

\section{Result and Discussion}

\begin{tabular}{lccc}
\hline \multicolumn{1}{c}{ Score } & $\begin{array}{c}\text { Before } \\
\text { treatment }\end{array}$ & Cycle I & Cycle II \\
\hline Average score & 68 & 71 & 75 \\
\hline Lowest score & 55 & 52 & 62 \\
\hline Highest score & 77 & 80 & 89 \\
\hline
\end{tabular}

Before the treatment, the researchers collected the students' average score of reading comprehension from the local English teachers of 6 vocational schools involved in this research. The scores were respectively noted 68 as the average score, 55 as the lowest score and 77 as the highest score. This was the starting point to decide how many cycles of treatment to be implemented for the next steps. Considerably, this action research was set to have 2 (two) cycles and in the end of each cycle, the students were given an objective test of reading comprehension. Each cycle consists of 4 (four) steps; planning, action, observation, and reflection.

In cycle I, students were still confused to cope with the Readutainment application (as it was a bit new thing for them) and faced problem with the internet connection. It was unfortunately less than $60 \%$ of students participating in cycle I. The achievement of reading test in the end of the first cycle proved to be unsatisfying reaching up to 71 for the average score; 52 for the lowest score (even decreasing from the previous score 55 before the treatment), and 80 for the highest score.

The researchers continued to do reflection by controlling and checking to get more students engaged in cycle II. Observation and reflection were done, previously, by analyzing all works executed in the cycle I. The observation was done indirectly through network to check students' participation to be present in the application. The researchers also visited directly to the real classrooms to gather students' learning problems in using e-learning. These all generated new plans and strategy, as a reflection, to apply in the next step. To continue the research to the cycle II, some texts needed to be changed with those within students' levels of knowledge and experience. For example, the texts of Indonesian prominent figures and national or international daily products were proven to enhance students' confidence in doing the exercise. It was worth doing since as an online course, Readutainment is offered as a distance education program. The content should be preconstructed (Anderson, 2010:41) appropriate with students' capacity so that they were able to connect with their previous knowledge to build comprehension (Woolley, 2011).

To overcome the problem of internet connection, the researchers distributed internet package data from provider which was familiar and easier to be accessed in these area freely to the students. However, group works were suggested and considered more helpful for students to deal with the application. It was more practical as only the leader or the representative of the group required to connect the internet when they got together to do the assignments after the school time. There was less complaint of internet connection from students afterwards. It was noted that as many as 165 students or $91.7 \%$ of the sample successfully submitted their works through the application in the cycle II.

Overall, the table below shows the students' reading comprehension achievements before treatment, in cycle I and in cycle II. It can be seen that in cycle II, the average score increases to reach 75 , the lowest score is 62 , and the highest score increases significantly to 89 .

\section{Conclusion and Suggestion}

As the impact of the fast growing technology, e-learning applied in a more creative teaching and learning model is worth implementing. This has led to the production of, for example, the Readutainment application, as one kind of innovation in technology, and is proven to have helped 
students involved and engaged with fun in the reading classrooms. The research question formulated in the current research is finally answered saying that the use of Readutainment application as e-learning can improve the students' reading comprehension skill. Nevertheless, in order to obtain a more general result, the next research is suggested to be conducted in the other places and the content of the application should be adjustably modified within the range of students' knowledge and experience in the new area of the research.

We hereby express our thanks to all parties who have directly and indirectly supported and contributed from the preparation till the completion of this research. Our special gratitude shall be delivered to the vocational schools in Singaparna and Leuwisari, West Java; the headmasters for their permission and the students of XI graders for their participation in this action research. We also wish to thank the Ministry of Research, Technology, and Higher Education who facilitated us with the fund to conduct the research, our beloved Prof. Dr. H. Sumaryoto, the rector of the University of Indraprasta-PGRI, Indonesia for his support and facilitation on this research. Finally, we wish to extend a special word of thanks to IEC4SD who facilitated us to join the conference.

\section{References}

1. N. Mohammadi, V. Ghorbani, F. Hamidi, Eff. of elearning on LL, Procedia Computer Science 3, 464468 (2011)

2. M. Marcellino, ELT in Ind: A Cont. Chall. in Ed. and Cult. Diversity, TEFLIN Journal, 19, 1 (2008)

3. T. Darmayanti, M. Y. Setiani, B. Oetojo, E-Learning pada Pendidikan Jarak Jauh, Jurnal Pendidikan Terbuka dan Jarak Jauh, 8, 2 (2007)
4. F. Daud \& A. Rahmadana. Pengembangan Media Pembelajaran Biologi Berbasis E-Learning, Jurnal Bionature, 16, 1 (2015)

5. Suharyanto dan A. B. L.Mailangkay, Pen. E-Learning sbg Alat Bantu Mengjr Dlm Dunia Pend., Jurnal Ilmiah Widya, 3, 4 (2016)

6. E. Iftanti, A Survey on the Eng. Reading Habits of EFL Students in Ind. TEFLIN Journal, 23, 2 (2012)

7. M. Sulhan, Map. Out The Teaching of Read. Compr. to SHS Students: A Bloom's Tax. Persp., Journal of Developing English and Language Teaching. 05, 3 (2015)

8. J. C. Richards, Extensive Reading in The Second Language Classroom, (Cambr. UP, UK, 1998)

9. R. Fox, Res-Based Strat. for Stud. with Learn. Disabil.: Focus on Phon. and Fluency. http://opus.ipfw.edu/grad_research/31

10. W. Kintsch and P. Mangalath, The Constr. of Meaning. Topics in Cognitive Science, 3, 346370.doi:10.1111/j.1756-8765.2010.01107.x

11. C. Blachowi \& D. Ogle, Reading Comprehension Strategies for Independent Learners. Second Edition (The Gulf. Press, NY, 2008)

12. Fischer, S. Roger A History of Reading, (React. Books, GB, 2003)

13. J. Anderson, ICT Transforming Education. (UNESCO, Bangkok, 2010)

14. G. Woolley, Reading Comprehension: Assisting Children with Learning Difficulties, DOI 10.1007/978-94-007-1174-7_2, C Springer Science +B. Media B.V. (2011) 